\title{
Murdoch and Canetti: A Woman's Writing and the Economy of Intertextual Appropriation
}

\author{
Fiona Tomkinson
}

\begin{abstract}
The paper discusses Iris Murdoch's novel $A$ Severed Head in terms of some of its intertextual resonances and, in particular, in terms of Murdoch's indirect references to Elias Canetti's Auto da Fé. Though the relationship between Murdoch and Canetti has been much discussed, this hidden dialogue with him has, to my knowledge, been hitherto undetected. I begin by placing my analysis in the context of the functioning of intertextuality in Murdoch's oeuvre in general. I then argue that these particular references function as a coded message to Canetti which is both a secret love-letter to her enchanter-figure par excellence and a means of incorporating and overcoming him.
\end{abstract}

Index Terms-Murdoch, Canetti, intertextuality, women's writing.

\section{INTRODUCTION}

In this paper I shall propose a reading of Iris Murdoch's 1961 novel A Severed Head in terms of its relationship to Elias Canetti's 1935 novel Die Blendung, better known in the English speaking world by the title of the 1946 translation by C.V. Wedgwood, Auto da Fé. I shall argue that what is at issue is not merely a question of general influence, but of subtle yet direct references to detailed aspects of the novel which it is highly likely were intended as coded messages to her lover Canetti himself. I shall also touch on other works which function as intertexts to A Severed Head, namely The Divine Comedy, Heart of Darkness and A Golden Bough, which also in their turn interact with Canetti's novel qua intertext.

My attempt to show the way in which these texts function within the novel is part of a larger project on the question of intertextuality in Murdoch. As is well known, Murdoch's works are very rich in references to other literary and philosophical texts, as well as to religious and mythical narratives and archetypes, and a great deal of secondary literature has been devoted to all of these. However, this criticism has, naturally enough, tended to propose 'readings of novels' in terms of particular schools of thought: Buddhist readings, existentialist readings, New Age feminist goddess-archetypal readings and many more. Most of these have a great deal of validity. But none of them have, to my knowledge, taken as their main focus the phenomenon of intertextuality itself, of the way in which one text works itself inside another's skin. Of course, it is never possible to detach this process entirely from any question of theme and content, of debate or dialectics. However, a writer as intensively, and I

Manuscript received November 9, 2015; revised March 12, 2016.

F. G. Tomkinson is with the English Language and Literature Department, Yeditepe University, Turkey (e-mail: fgtomkinson@yahoo.co.uk). would dare to say as self-consciously intertextual as Murdoch invites us to attempt a descriptive phenomenology of the operations of intertextuality itself, a process which is, all the more fascinating the more shadowy the presence of the intertext, the more elusive the allusion.

It is, of course, impossible to prove that all the connections which a critic may make between a text referred to or alluded to in a given Murdoch novel were consciously intended by the author, yet once such an intertext has been detected it creates what I call an interrealm between itself and the main narrative, a realm of manifold connections and perspectives, and it is this which I shall be attempting to analyse.

\section{INTERTEXTUALITY IN MURDOCH}

Many of Murdoch's intertexts are, of course, the opposite of shadowy: for example, in An Unofficial Rose, we have characters based on well-known figures from Dickens and Shakespeare: the Miss Haversham of Great Expectations (Murdoch, 2000) [1] and the Miranda and Caliban of The Tempest: the big clue is that the Miranda character is called Miranda, though even here there is a serious twist to the tale, in that, as Anthony D. Nuttall points out, in his introduction to the novel, the Caliban character is good, and the Miranda character is not good [2] (Nuttall 2000: 3).

In many other cases, the reader has to work a lot harder and an acquaintance with less well-known texts is called for. It is very often the case in Murdoch's novels that a brief reference to a text or to a legendary figure resonates throughout the novel, one might even say permeates it, giving an added perspective to our perception of characters and events or perhaps functioning as a Gestalt against which we perceive them.

For example, in The Nice and the Good, a case can be made out for Njal's Saga, The Aeneid and Coleridge's 'Kubla Khan' [3] (Tomkinson, 2011: 252-260) functioning as such intertexts, and a reading of The Green Knight is much enhanced if one recognises its repeated allusions to Auerbach's Mimesis. [4] (Tomkinson 2010: 81-90). Identifying an intertext does not mean that the plot will necessarily unfold, or the characters reveal themselves, in the same way as their counterparts in the intertext, if the intertext is a fiction, nor in the case of a philosophical text should we conclude that Murdoch is in fact espousing that particular philosophy and using her novel as an illustration of it. In fact, very often exactly the opposite is the case.

On some occasions, the plot of the Murdoch novel follows a pre-existing plot in some ways, but also departs radically from it in others: a passage in Murdoch's penultimate novel, The Green Knight, has a character explicitly pointing out this 
mixed up and messy relationship between the events that have unfolded and the plot of the novel's most obvious intertext: the medieval romance Sir Gawain and the Green Knight. We have in such cases an intertextual reference which is simultaneously clearly defined, because the allusion has been spelled out for us, and also in another way, extremely fuzzy around the edges. [4] (Tomkinson 2010: 81-90) The effect seems to be deliberate, and is perhaps related to Murdoch's views on the question of mimesis, which one can very crudely summarise as the belief that there is a world out there beyond texts with which it is the business of the novelist to engage, and that reality, despite its serious repetition compulsions, never plays exactly the same game twice.

Many intertexts are indeed highlighted just to make the point that the story of the novel will not proceed as it would have done in that other work of art. For example, towards the end of The Green Knight, a character puts down $A$ Glastonbury Romance and picks up Pride and Prejudice, thus signalling a happy end for the novel rather than the tragic one of drowning which so nearly takes place. This ploy of a character physically handling a particular text, as a way of signalling intertextuality is very common in Murdoch novels and is there at the very beginning of her oeuvre when we find Jake Donaghue with French existentialist texts literally as well as metaphorically in his baggage at the beginning of Under the Net.

\section{INTERTEXTS IN A SEVERED HEAD}

In $A$ Severed Head we are given a number of such hints regarding texts which may throw light on the first-person narrative of tangled, adulterous and incestuous relationships which we are reading. In the second chapter of the novel, the narrator, Martin Lynch-Gibbon, gives us an account of his close friend, the psychoanalyst, Palmer Anderson as he appeared to him in the early days of their friendship when 'We used to read Dante together' [5] (Murdoch 2001: 16) This is before Palmer emerges as the seducer of first Martin's wife, Antonia, and, finally, his mistress Georgie. In the intervening pages, Martin falls in love with Palmer's sister, the anthropologist, Honor Klein, only to discover Palmer's incestuous relationship with her. Martin then loses his mistress to his brother Alexander, who then emerges as the long-term lover of Antonia: a revelation which results in a suicide attempt by Georgie.

The novel ends with a comic resolution in the sense that everyone is paired off; Antonia with Alexander, Palmer with Georgie, and Martin with the enigmatic Honor, but what Martin has experienced in order to arrive at this point is very clearly identified as a descent into hell.

The word infernal is used repeatedly, and there is even a rough correspondence to the descending circles of Dante's inferno, through lust, overindulgence, anger, depression, violence and the final shocking discoveries of betrayals by kin.

On the other hand, Martin's love for Honor Klein is at one point explicitly identified with that of Dante for Beatrice, and, in contrast to the infernal London fog which surrounds the greater part of the action the revelation of Honor's incest takes place against a backdrop of Cambridge starlight which recalls the references to the stars at the end of each of the three books of The Divine Comedy.

However, the ambivalence of the character of Honor is, to a great extent, a consequence of the variety of intertexts she brings into play. She is not only Beatrice.

Alternatively, the novel could be seen as a journey into a heart of darkness: Honor Klein's surname, which means 'small' in German, recalls that of Conrad's mysterious protagonist, Mr Kurtz ('short' in German) Both Klein and Kurtz are involved with primitive tribes, whilst Kurtz has a collection of severed heads, Honor is seen as 'a severed head such as primitive tribes and old alchemists used to use, anointing it with oil and putting a morsel of gold upon its tongue to make it utter prophecies' [5] (Murdoch 2011:185) and her exercises with a samurai sword are more than suggestive of decapitation [5] (Murdoch 2011: 95-97).

Falling in love with Honor leads Martin to abandon his usual reading matter, military history, in favour of The Golden Bough and other works of anthropology, focusing on totem and taboo, and most especially, the taboo of incest. The figure of Honor Klein is thus associated simultaneously with the high points of love literature in the Western canon and with all that is savage and atavistic outside it, and may indeed make us question whether there is indeed a great qualitative difference between the two.

\section{REFERENCES TO CANETTI IN A SEVERED HEAD}

The intertextual relationship with Canetti's magnum opus may seem, at a first glance, less obvious. What can be the connection between a tale of upper-middle-class adulteries and the grotesque story of Peter Kien, reclusive and eccentric sinologist and bibliophile, who descends into madness and finally burns himself in his beloved library as a result of the disturbance to his studies caused by an impulsive and never consummated marriage to an uneducated housekeeper in a starched blue skirt who takes over his rooms, is the cause of him walking around with eyes closed to avoid seeing the furniture she has introduced into his study, demands that he make a will, beats him up and exiles him from his flat into a world where he is the dupe of a hunchbacked dwarf and would be World Chess Champion who has him hand over money to his accomplices to save books from being pawned and eaten?

Murdoch scholarship in recent years has recognised that Murdoch's relationship with Canetti was of longer duration and greater importance than had been previously considered, and there has been a long-standing tendency to interpret dark and powerful male enchanter figures in Murdoch novels as portrayals of Canetti himself. Rowe [6], Morley [7] and Horner [8] have all shed light on the intricacies of this relationship, the extent to which Murdoch was fascinated by Canetti and the impact of this fascination on her writing. There has, however, not been, as far as I am aware, any attempt to bring together Die Blendung and A Severed Head.

The first hint of a connection might, however, be found in the title itself, which brings to mind the three sections into which Die Blendung is divided: 'A Head without a World'; 'Headless World' and 'The World in the Head'. The second 
hint is in the dedication, or rather its absence. As Valerie Purton has pointed out in an article in the 2008 Iris Murdoch Review, 'Iris Murdoch and the Art of Dedication', Murdoch took her dedications extremely seriously, and many of her books are dedicated to people with whom she had, or wished to have, sexual relationships. Only two of the novels are without dedicatees: her last novel, Jackson's Dilemma, which was written when she was on the verge of succumbing to dementia and whose quality she possibly doubted, and $A$ Severed Head. [9] (Purton 2008, 28) Her second novel, The Flight from the Enchanter had daringly been dedicated to Canetti, her own enchanter-figure, only for him to criticise in a meeting of 29 January 1959 the 'blandness' of her subsequent novels The Sandcastle and The Bell [9] (Purton 2008: 28).

Bearing all this in mind, it is plausible that there is no dedication to A Severed Head, just because it is a response to Canetti, but she does not wish to repeat the act of dedication, which would have been all the more indiscreet after her 1956 marriage to John Bayley (which did not, however, mean the end of her sexual relations with Canetti), and perhaps also because she thinks he does not entirely deserve a second dedication and wishes to punish him by withholding it. The response, however, goes beyond the selection of something less 'bland' in the incestuous relationship of Palmer and Honor.

I would like to single out three aspects of A Severed Head in which connections can be made to Die Blendung. The first is the general theme of Blendung or bedazzlement. Perhaps no author, with the exception of Cervantes, has created a major work in which a protagonist so routinely and grotesquely misinterprets the world outside books as Canetti's hero, or anti-hero, Kien. His initial delusion that his housekeeper is in love with him is nothing when compared to his belief that he carries a library around in his own head which needs to be unpacked every night, or that he has murdered the wife who threw him out by locking her in to starve - a wish-fulfilling delusion which makes him dismiss her physical reappearance as a hallucination.

Moreover, all Canetti's other protagonists, besotted women, conmen, policemen, criminals, bureaucrats and psychiatrists, all grossly misinterpret the world in general, and other people in particular, in terms of their own desires. Kien's wife believes she looks thirty when she is fifty-seven and that men look at her in the street to admire her magnificent figure rather than to deride her ridiculous skirt. The hunchback Fischerle lives in dreams of the palace and millionairess that his world chess championship will bring, only to be murdered by the fake blind man accomplice who could not countenance his insulting parting gift of a button. In the same way, Murdoch's protagonist, Martin, stumbles through external and internal fogs, routinely deceived by, or failing to understand, all those closest to him.

A second and more detailed parallel can be found in the use which Murdoch appears to have made of the character of George, the psychiatrist brother of Peter Kien, who appears in the final section of the novel to liberate his brother from his persecutors, his wife and the caretaker who has seduced her, and restore him to his library, but who underestimates the severity of his madness and therefore abandons him to his fate of self-immolation. If, as Morley argues, Murdoch has in The Time of the Angels combined two characters from Die Blendung, Kien and the brutal incestuous caretaker, Benedict Pfaff, in order to create the intellectual Carel Fisher who also commits incest with his daughter (and whose name resembles that of Fischerle the hunchback), in A Severed Head she seems to have divided one of Canetti's characters in two in order to come up with Martin's brother Alexander and the analyst Palmer Anderson.

Palmer Anderson is described as a fashionable psychoanalyst who had first been an ordinary though successful medical doctor, whilst George Kien, a character often thought to be based on Canetti's own brother George, is described as having been a gynaecologist before becoming the adored and famous director of a lunatic asylum. Both George and Palmer are obsessed with understanding their patients in a non-judgemental way, but are revealed as ultimately flawed and egotistical. Both George and Alexander seem to have had a relationship of childhood rivalry and competition for a mother's love with their sibling which plays a role in their adult decisions. The fact that Peter Kien identifies himself with Alexander the Great at a memorable point in his childhood, when the thought of the cutting of the Gordion knot leads him to smash rather than prise open a mussel shell, and that the name George, or rather Georgie, appears as that of Martin's mistress in A Severed Head suggests that Murdoch may well have being deliberately playing around with names from Canetti's novel.

Finally, on the level of close reading one passage in particular suggests a link with Die Blendung. This occurs at the point where Martin goes to deliver a crate of expensive wine to his separated wife and Palmer only to find them in bed together.

In his drunkenness, he spills wine on the carpet and ends up apologising and backing out in a shamefaced manner. On the surface everyone's behaviour is the epitome of the civilised.

However, Palmer's will-to-power manifests itself in his final request to Martin to take the crate of wine down to the cellar on the pretext that it is unsafe to leave it in the corridor when maids and paper boys will be arriving in the early morning. This trip to the cellar leads to the pivotal action in the novel: Martin's encounter with Honor Klein, whom he pushes to the floor and beats: an action which makes them both understand that he is in love with her.

In the encounter in the bedroom which leads to this, Martin says to Palmer and his wife: 'Ares and Aphrodite.' Palmer replies, 'But you are not Hephaistos, are you, Martin?' [5] (Murdoch, 2001: 107) Reading this passage in the light of the use of the Ares/Aphrodite myth in Die Blendung reveals the dark depths lurking behind what might seem a civilised exchange of pleasantries. Towards the end of Canetti's novel we are given a description of the madhouse run by George Kien. This includes a character called Jean, a blacksmith who had lost his livelihood and in consequence been deserted by his wife who had run away with a sergeant. When the neighbours confiscate his furniture to settle his debts he revenges himself in a terrible manner:

Jean laughed and set fire to the village. Out of the burning house of his cousin he salvaged his wife's bed. Before he took 
it away he strangled the little children asleep in it, three boys and a girl. He gave himself a lot of work that night.

(Canetti 2005: 408 [10])

He then finds himself in a cell with a schoolteacher who tells him:

Your name's Vulcan! You squint and limp. You are a blacksmith. A good blacksmith if you limp. Catch your wife!

(Canetti 2005: 408 [10])

He then explains the story of Mars, Vulcan and Venus, which eventually becomes the basis of the therapy which George Kien applies to Jean: that of humouring his delusions and telling him that his absent wife is in the net in which he has caught her. Finally, George himself tires of this therapy and advises Jean to 'hit her on the head' (Canetti 2005: 413 [10]) The Ares-Aphrodite story is also referred to by Peter Kien as one element in his final obsessive misogynistic diatribe (Canetti 2005, 440 [10]). What then are we to make of this connection? On the one hand, the story of Jean the blacksmith can be seen as emphasising the dark side of the passions which Murdoch describes; on the other hand, we might consider her allusion to the legend a domestication and prettification of the brute forces at work in the world presented by Canetti.

\section{CONCLUSION}

A final and related question is, what coded message to Canetti was Murdoch sending in all of this? Perhaps the most obvious message was the actual fact that she was alluding to his work at all, signalling her continued interest in him as a writer and as a man. If a critique was also involved, doubtless any critique of the person one is obsessively in love with, as from surviving correspondence [6] it seems Murdoch was with Canetti, is nothing but oblique praise. She is also clearly paying conscious tribute to his philosophical critique of the isolated autonomous 'Kantian' individual, who is incapable of seeing the other.

More personal aspects we can only guess at. Is the character of Alexander, who seduced all Martin's girlfriends before Antonia and Georgie, a satirical comment on Canetti's fraught relations with his own brother George, whom Canetti's wife was in love with, but, who, somewhat unfortunately for her, happened to be homosexual? I believe it is also the case that Murdoch, playing Arendt to Canetti's Heidegger, is also suggesting through her creation of the troubled, bedazzled, yet comparatively benign and ultimately joyous world of A Severed Head, that the universe is not so dark and humanity not quite so wretched as they appear to be in their presentation by the author of Die Blendung. Moreover, her very act of writing, as a female writer still at a relatively early stage in her career, her engagement with and appropriation of canonical texts from a male-dominated literary tradition and from a dominant male figure in her life can be seen in itself as an act of resistance and rebellion and a step on the path which was to lead her to surpass Canetti in literary fame.

\section{ACKNOWLEDGEMENT}

Fiona Tomkinson thanks Yeditepe University for facilitating this publication.

\section{REFERENCES}

[1] I. Murdoch, An Unofficial Rose - An Introduction by Anthony D. Nutall, London: Vintage Books, 2000.

[2] A. D. Nuttall, Introduction to an Unofficial Rose, London: Vintage Books, 2000.

[3] F. G. Tomkinson, "Gunnar's cave: An intertextual reading of Iris Murdoch's the nice and the good," in IDEA: Studies in English, E. D. Adanur, Ed. Newcastle-upon-Tyne: Cambridge Scholars Publishing, 2011, pp. 252-260.

[4] F. G. Tomkinson, "Intertextuality in the green knight," in Iris Murdoch and Her Work: Critical Essays, M. Kırca and Ş. Okuroğlu, Eds. Stuttgart: ibidem-Verlag, 2010, pp. 81-90.

[5] I. Murdoch, A Severed Head - An Introduction by Miranda Seymour, London: Vintage Books, 2001.

[6] A. Rowe, "I embrace you with much love: Letters from Iris Murdoch to Elias Canetti," The Iris Murdoch Review, no. 1, pp. 37-40, 2008.

[7] E. Morley, "Iris Murdoch and Elias Canetti: Towards a reassessment," in Iris Murdoch: Texts and Contexts, A. Rowe, Ed. Palgrave Macmillan, 2012, pp. 145-159.

[8] A. Horner, "The "wondrous necessary man": Canetti," in Iris Murdoch: Texts and Contexts, A. Rowe, Ed. Palgrave Macmillan, pp. 163-176.

[9] V. Purton, "Iris Murdoch and the art of dedication," The Iris Murdoch Review, no. 1, pp. 28-36, 2008.

[10] E. Canetti, Auto da Fé, C. V. Wedgwood, Trans. London: The Harvill Press, 2005.

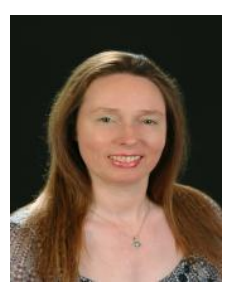

Fiona Tomkinson was born in Stoke-on-Trent, England on August 2nd, 1965. She holds a BA and MA degrees in English language and literature from Oxford University, 1987 and 1991, and an MA degree in 2000 and a PhD degree in 2008 in philosophy from Boğaziçi University, Istanbul.

She is currently an associate professor in the English Language and Literature Department at Yeditepe University, Istanbul, where she has worked since 1997. She previously taught at Doğuş University, Beykent University, English Fast Istanbul, Stevenson College Edinburgh, INKUR language school (Izmit), the Oxford Business College and the Oxford Intensive School of English. She has also worked part-time as a translator, freelance and for Mirora translation agency. She has published over sixty articles in the fields of literature and philosophy as well as translations from French, German and Turkish, mainly in the areas of poetry and philosophy.

She is a member of the Iris Murdoch Society and the Iris Murdoch Society of Japan, the Lawrence Durrell Society (Member at Large of the Executive Committee, 2012-14), the Elizabeth von Arnim Society and the Arnold Bennett Society. She edits the Yeditepe journal Septet, was a member of the Organisation Committee of the International Philosophy Colloquium, 'Martin Heidegger and Hannah Arendt: Metaphysics and Politics', May 29th-30th, 2000, Istanbul and has been Colloquium Organiser since fall 2009 of the English seminar series at Yeditepe. In December 2015, she was awarded the Arda Denkel prize for achievement by former philosophy students with $\mathrm{PhDs}$ from Boğaziçi University. Her poetic drama Beowulf A Verseplay was performed in the Quays Theatre, Manchester in June 2014. 